\title{
A NAÇÃO COMO RELATO \\ A estrutura narrativa da imaginação nacional
}

\section{Francisco Colom González}

\author{
Tradução de Rubem Barboza
}

O pensamento sociológico interessou-se tradicionalmente por determinar o momento em que acabam os antigos sistemas de crenças e começam as ideologias modernas. Nas sociedades sustentadas sobre opiniōes e regras de vida sacralizadas pelo tempo, cujas instituições políticas obedecem ao que Weber denominou a legitimidade tradicional, a ideologia desempenha papel marginal. Ao contrário, quando a mudança social produz a impugnação de tais percepções, aumenta a necessidade de se encontrar formulações que as substituam. O nacionalismo ocupa uma posição central no repertório das ideologias modernas. Apresenta, no entanto, uma peculiaridade cognitiva: um deslocamento sistemático entre a percepção que seus atores têm de si mesmos, de suas ideias e objetivos, e a dinâmica social reconhecível por trás deles. As miragens que, em maior ou menor grau, povoam todos os credos

Artigo recebido em 08/08/2011

Aprovado em 05/03/2012 políticos levaram o marxismo a identificar a noção de ideologia como uma forma de falsa consciência. De fato, alguns autores desta orientação continuam vendo nos movimentos nacionalistas a consumação deturpada de um imperativo histórico dirigido originalmente à liberação do proletariado. A determinação do componente fictício ou enganoso das representações ideológicas superou os confins iniciais do marxismo e recebeu desde então múltiplas formulações: naturalização das desigualdades, mascaramento de interesses particulares, distorção sistemática da comunicação, câmera escura em que a relação entre os homens parecem invertidas etc. (Lenk, 1982). Nesse sentido, os relatos nacionalistas costumam descrever o retorno à vida de povos ancestrais ou à luta secular destes povos pela sua liberação política. $\mathrm{O}$ estudo objetivo mostra, pelo contrário, que as nações não são entidades naturais ou dormentes à espera de um despertar heroico e tampouco uma mera invenção de intelectuais res- 
sentidos. As nações não são o que parecem e, sobretudo, não são o que o nacionalismo enxerga nelas. As identidades nacionais podem ser definidas como estados mentais propiciados por histórias ou por uma imaginação histórica narrativamente configurada. As palavras, no entanto, nunca são inocentes. As doutrinas nacionalistas recorrem ao relato para alcançar profundeza histórica e densidade ética, conferir sentido ao passado e se impregnar de razões no presente. Se na literatura as questôes de fato ou de verdade se submetem ao fim poético de criar uma estrutura autônoma de palavras, na retórica política em geral, e na nacionalista em particular, o uso evocativo dos tropos fica subordinado à sua função constitutiva da subjetividade. O discurso nacionalista tende, assim, a recriar o passado coletivo como uma trajetória semeada de causas nobres, sacrifício trágico e cruel necessidade. Para isso serve-se de artifícios culturais de natureza muito distinta: relatos literários, narrações históricas, rituais comemorativos, representaçóes visuais etc. Todos esses dispositivos mostram sua funcionalidade quando se procede à manipulação inventiva da história com o fim de conceder à identidade nacional a aparência de uma existência ininterrupta no tempo.

Contudo, o vínculo comunitário que une os membros da nação é tão só metafórico, uma construção narrativa, e as metáforas podem ser eficazes na nossa imaginação ou não significar nada. $\mathrm{Na}$ literatura, os critérios externos de significação são secundários (Frye, 1957). Verdade e mentira são, desse modo, categorias epistemológicas que resvalam sobre a condição nacional, sem penetrá-la: as nações não são verdadeiras ou falsas em virtude da sua atribuível existência ou inexistência. A nação é uma referência identitária normativamente construída, cujos elementos prescritivos são inseparáveis dos descritivos. As falsidades e as mistificações se introduzem no processo político de sua elaboração narrativa, ou seja, na dinâmica ideológica do nacionalismo. Esta dinâmica, por sua vez, deve se inserir em processos de maior alcance, pois os recursos simbólicos do nacionalismo mais do que tudo expressam a própria mudança social. A mobilização em nome da nação tendeu a aparecer, por isso, em contextos de intensas e aceleradas transformaçōes sociais: no ocaso do Antigo Regime, na Revolução
Industrial, na decomposição dos grandes impérios europeus, na descolonização do Terceiro Mundo e, mais recentemente, na derrocada dos regimes comunistas. A imaginação nacional reflete o trânsito do direito divino à soberania popular, dos impérios multiétnicos aos Estados nacionais, da dependência colonial ao autogoverno, das identidades locais à cultura de massas. A emergência da nacionalidade como fundamento de legitimação significou a superação das velhas concepções contratualistas sobre a soberania e a singularização cultural de uma nação. Para além desta constatação, a elaboração de uma teoria geral sobre o nacionalismo constitui uma empresa bastante arriscada. Sob um mesmo termo tendem a se subsumir momentos e experiên cias históricas nas quais os papéis jogados pelas classes sociais, as estruturas econômicas e políticas, as ideologias, a etnicidade, a religião e a violência se combinaram de forma muito diferente. Pouco há em tudo isso que possa se entender como um retorno às raízes ou uma reação primordial ante o desconhecido. $\mathrm{O}$ nacionalismo postula um tipo de identidade cultural entre governantes e governados que não é possível sem a homogeneidade propiciada pelos instrumentos da moderna soberania política. Por isso costuma ser verdadeiro o axioma segundo o qual os nacionalistas criam o Estado e o Estado cria a nação.

Os processos de construção nacional caracterizaram-se por homogeneizar e fundir em uma referência única as adscrições culturais dos indivíduos através de processos de socialização politicamente dirigidos. Os relatos históricos sobre as origens, o devir e o futuro da nação constituem a dimensão mais visível deste processo. Neles, a pergunta pela identidade coletiva deve ficar respondida desde o início, já que disso depende a inteligibilidade de uma narração dirigida àqueles convidados a se sentirem membros de uma comunidade de destino. A rememoração dos momentos fundacionais, os pactos, os documentos e os sacrifícios que forjaram a soberania ocupam local privilegiado em tais histórias. Nelas é recolhida a legitimidade de origem e o propósito histórico do rumo da nação. O papel da intelligentsia em todo este processo é decisivo, porém não podemos ver tão só no nacionalismo os interesses específicos de uma classe beneficiada pela 
institucionalização das culturas nacionais. A etnificação das estratégias políticas é uma possibilidade a mais em contextos de incerteza social, onde a ativação dos vínculos de pertencimento proporciona novas identidades sob o véu do ancestral, ilumina o espectro de alianças possíveis e identifica os potenciais adversários.

As análises convencionais da ideologia pecaram frequentemente por um preconceito epistemológico: o de concebê-la como um sistema pré-configurado de símbolos. De fato não existe um nexo causal que permita atribuir determinados repertórios simbólicos a situaçôes concretas de tensão social. Clifford Geertz é talvez quem melhor viu este preconceito ao resumi-lo em duas formas de interpretar a ideologia, rotuladas respectivamente como teorias do interesse e da tensão:

Para a primeira, a ideologia é uma máscara e uma arma. Para a segunda, é um sintoma e um remédio. Segundo a teoria do interesse, os pronunciamentos ideológicos hão de se ver sobre o fundo de uma luta universal para conseguir vantagens. Segundo a teoria da tensão, respondem a um permanente esforço por corrigir o desequilíbrio sociopsicológico. Para uma, os homens perseguem o poder; para a outra, fogem da ansiedade (Geertz, 1987, p.177).

A grande vantagem da teoria do interesse, cujo melhor exemplo é oferecido pelo marxismo, reside em enraizar os sistemas ideológicos no terreno da estrutura social. Sua indubitável originalidade teórica tendeu a se diluir, contudo, pelo rudimentar caráter das conexôes que estabelece entre os fatores materiais, psicológicos e culturais da ação social. Como adverte ironicamente o próprio Geertz, a psicologia deste esquema é anêmica demais e a sua sociologia musculosa demais. Por outro lado, a teoria da tensão, na medida em que obedece a conceitos desenvolvidos a partir do estudo da personalidade e dos sistemas sociais, dá por suposto um desequilíbrio estrutural permanente. $\mathrm{O}$ modelo empregado aqui não é estratégico, mas terapêutico: o pensamento ideológico representaria a resposta a um sintoma, o do desespero provocado por expectativas sociais contraditórias, e ofereceria uma saída simbólica à ansiedade provocada por formas deficitárias e tendencialmente anômicas de socialização. O nacionalismo se encaixa, comodamente, nas explicaçôes articuladas segundo o esquema terapêutico, já que este tende a enfatizar a função catártica dos "ideologemas" nacionalistas, sua força moral, capacidade solidária ou utilidade expressiva. Ao apresentar o nacionalismo como um sucedâneo moderno da religião, este tipo de interpretação seguiu uma estrada inversa à de Max Weber e de sua teoria do desencantamento do mundo. Porém, além das concepções estratégicas ou terapêuticas do nacionalismo e suas ideologias, a chave de sua eficácia mobilizadora apoia-se em sua capacidade para gerar novas redes de significados sociais.

\section{Narrar a nação}

A concessão de novos significados às relaçōes humanas em contextos de rápidas transformaçōes sociais depende em boa medida dos processos simbólicos que as acompanham. A nação apresenta-se a partir dessa perspectiva como um sistema de representaçóes dotado de uma natureza textual, pois se constrói em última instância sobre os relatos da identidade nacional e, mais concretamente, mediante um tipo de narração que caberia qualificar de ontológica (Somers, 1994). Estas histórias fornece-nos a razão de quem somos como condição prévia para saber o que devemos fazer. O conjunto de relatos que define as identidades nacionais supōe uma codificação do memorável, um sistema de fiação de significados dirigido a motivar uma autopercepção coletiva. Os dispositivos culturais ativados politicamente procuram impulsionar um relato da identidade coletiva que permita aos indivíduos se reconhecer em uma continuidade social que se desdobra no espaço e no tempo. Os relatos da identidade nacional são também, nesse sentido, narraçōes públicas, ligadas, portanto, a redes sociais e instituições, e se encontram submetidos a pressóes de legitimação. Evidentemente, a estrutura dos relatos nacionais varia com cada circunstância e lugar. Distintos relatos podem e de fato costumam brigar para atingir um status hegemônico na imaginação coletiva, e além de suas diferenças e semelhanças 
estruturais devem ser capazes de resolver simbolicamente os conflitos do substrato social em que se geram. $\mathrm{O}$ grau de virulência e exclusividade dos nacionalismos está até certo ponto relacionado com sua natureza narrativa, com o tipo e os conteúdos das histórias que contam, pois o que se constitui em matéria de rememoração é ao menos tão importante quanto o modo como se lembra. A conclusão de tudo isso é que as identidades, a diferença dos constructos jurídicos, precisam ser contadas para poderem ser apreendidas.

A sequencialidade é um elemento duplamente transcendental da condição narrativa, porque não só permite a organização dos acontecimentos em um enredo: a própria capacidade de atribuir uma dimensão normativa às identidades depende $\mathrm{da}$ possibilidade de inseri-las em um esquema de temporalidade histórica. Só se pudermos nos identificar com referências coletivas projetadas imaginariamente para o passado, seremos capazes de conjugar os tempos históricos do pronome nós. Essa figuração moral é a que nos permite, eventualmente, assumir responsabilidades históricas, reclamar compensações ou privilegiar uma determinada filiação genealógica em nossas identidades. Isto é algo que Paul Ricoeur percebeu claramente ao afirmar que o tempo se torna humano quando se articula de modo narrativo (Ricoeur, 1983). As identidades adquirem seu potencial normativo no seio da história configurada como temporalidade dotada de sentido. Entre a atividade de narrar uma história e a natureza temporal da existência humana se dá, para Ricoeur, uma necessidade circular: o tempo é articulado de um modo narrativo e, inversamente, a narração, seja histórica ou fictícia, atinge sua plena significação quando é convertida em condição da experiência temporal. Isto ocorre porque a narração imitaria criativamente a experiência temporal viva, em vez de se limitar a reproduzi-la de forma passiva. A temporalidade translada-se para a linguagem na medida em que esta configura nossa experiência temporal, confusa e informe, para reordená-la. A função narradora opera assim esquematicamente, no sentido kantiano do termo, já que em virtude dela fins, causas e contingências são reunidas na unidade temporal de uma ação total e completa. $\mathrm{O}$ receptor da narração é quem assume a unidade de todo o percurso narrativo, pois no enredo o tempo narrado se representa diacronicamente, como acontecer, permitindo que a história seja dotada de uma finalidade própria. Ao captar o final do enredo no começo e o começo no final, aprendemos a ler o tempo ao contrário e a identificar as condições iniciais de um curso de ação em suas consequências finais. $\mathrm{O}$ enredo, então, dispõe os fatos e encadeia sequencialmente a ação constitutiva da história narrada.

Não é preciso compartilhar os supostos fenomenológicos de Ricoeur - a ideia de que existe uma estrutura pré-narrativa da experiência - nem sua concepção kantiana do método hermenêutico para reconhecer a importância de sua análise para o estudo das identidades políticas e, mais concretamente, dos dispositivos simbólicos do nacionalismo. A construção do passado está aberta a distintas possibilidades narrativas - não há um passado fechado para sempre. As opções em um ou outro sentido são invariavelmente interessadas e encontram-se submetidas às tensões sociais do momento. Para os propulsores da independência mexicana, por exemplo, não significava o mesmo identificar as origens da nação em Hernán Cortés ou em Cuauhtémoc. A construção da imaginação nacional implicava uma profunda mudança na autoidentificação coletiva das classes dominantes novo-hispanas, pois "a gente não se deita um dia sendo espanhol diante dos índios e das castas e se levanta no dia seguinte sendo mexicano diante dos espanhóis" (Pérez Vejo, 2004, p. 293). Contudo, quando no México daquele tempo debate-se sobre a Espanha e os espanhóis, o que se está discutindo de fato é sobre o México e os mexicanos.

Cada relato da identidade nacional nos remete, então, a uma imaginação histórica distinta e guarda em seu seio uma intencionalidade prática. Porém, nem todas as naçôes se imaginam do mesmo modo, nem são iguais as consequências do triunfo de um ou outro tipo de imaginação histórica. As variantes étnica, cívica e religiosa da nação refletem, cada uma a seu modo, a genealogia intelectual que acompanhou seu respectivo processo de construção política. $\mathrm{Na}$ história convencional das ideias, a cidadania costuma se apresentar como o núcleo do legado igualitário da Revolução Francesa. A nacionalidade, pelo contrário, aparece pouco 
menos que como um lastro culturalista introduzido pelos românticos alemães no programa racionalista da Ilustração. A cidadania permitia a participação política direta em uma sociedade que acabava de ser liberada das mediações do estamento - a casta, o grêmio e o parentesco. O pertencimento nacional oferecia um bem de índole distinta: estabilidade e tradição ante a vertigem da história. Por trás de cada uma destas correntes, exercitava-se uma concepção distinta da política e, em última instância, do conhecimento humano. Para a imaginação liberal, o alumbramento da nação soberana é associado a um momento constituinte de índole contratual. Esse momento é inseparável da pergunta pela identidade coletiva. Contudo, o sujeito do processo de autofundação que arranca com "nós o povo é de fato um pressuposto, não um derivado do ato fundador. A lógica circular que caracteriza todo momento constituinte supõe um autêntico desafio para a imaginação política, já que por meio de um ato jurídico é criado um sujeito coletivo que toma em suas mãos as rédeas do seu destino, mas que de algum modo antecede e protagoniza o ato de sua própria constituição. A identidade do demos é, então, uma questão que carece de resposta na doutrina liberal, porém para os forjadores de nações resulta indispensável. Por isso o liberalismo teve que construir a sua estrutura de garantias e contrapoderes sobre identidades coletivas cujos fundamentos se encontram localizados além da esfera dos interesses normativos estritamente liberais. Os argumentos para legitimar a construção da nação liberal tenderam a beber na imaginação histórica e, mais concretamente, em uma interpretação estilizada dos velhos direitos feudais. Esse recurso historicista aludia de modo geral à perda das liberdades primigênias de origem germânica - como o jugo normando dos revolucionários ingleses, a Franco-Gallia dos monarcómacos franceses ou a tradição goticista espanhola -, embora seus argumentos fossem rapidamente substituídos por outros extraídos do etnicismo romântico e positivista.

A religião é uma chave a mais na determinação dos imaginários nacionais. Anderson assinalou que a força coesiva do nacionalismo não pode ser explicada sem a sua justaposição aos grandes sistemas culturais que o precederam, fundamentalmente a comunidade religiosa e o reino dinástico (Anderson, 1992). Antes do surgimento do Estado liberal, a homogeneização cultural que a nação pressupõe só pôde se desenvolver mediante os processos de aculturação religiosa desatados pela Reforma protestante. $\mathrm{O}$ princípio cuius regio, eius religio, sob o qual foi selada a Paz de Augsburgo em meados do século XVI, respaldou a particularização da simbiose medieval entre as legitimidades política e religiosa, abrindo assim uma margem histórica para a irrupção das nacionalidades. Porém foi durante as lutas entre a coroa e o parlamento inglês, que a nação veio a designar pela primeira vez aqueles com quem o soberano devia pactuar para exercer seu domínio legítimo: uma grei de crentes catequizada em língua vernácula e reafirmada na sua autonomia religiosa e cultural em relação a Roma e ao latim litúrgico. Este é o motivo que levou alguns autores a ver na Inglaterra a primeira nação moderna (Hastings, 1997). A nação assim definida abarcava apenas um seleto grupo delimitado por privilégios estamentais e de classe, mas abrigava ao menos o germe da inclusão: pela primeira vez aludia ao povo soberano e reafirmava as liberdades dos seus membros em face das prerrogativas do monarca. A paulatina multiplicação do controle sobre os poderes monárquicos permitiu singularizar étnica e geograficamente o povo soberano definido pelas teorias do contrato social. A nação deixou então de designar exclusivamente uma das partes constitutivas do pacto de soberania, para se referir a uma entidade política entre outras similares inseridas em um incipiente sistema de relações recíprocas. A imagem da nação vinculada ao monarca daria lugar paulatinamente à imagem da nação em contraponto a outras nações e, com isso, ao problema de definir uma ordem inter-nacional.

O relato histórico foi um dos principais recursos mobilizados no processo de construção das identidades nacionais, sobretudo a partir da emergência da historiografia romântica. Ao se interrogar pela essência das nações na sua famosa palestra de 1882, Ernest Renan já estava plenamente consciente da importância da memória histórica para a coesão nacional (Renan, 1992, p. 41). Em sua intervenção apelou ao componente voluntarista $\mathrm{da}$ nação, ao desejo expresso que sua existência supóe 
de continuar uma vida em comum, mas também assinalou a necessidade do esquecimento, e mesmo do erro histórico, na construção de sua identidade. Renan tinha em mente as nações dotadas de uma existência política reconhecível e, particularmente, a querela franco-alemã sobre Alsácia e Lorena. É preciso lembrar que um século antes, durante a Revolução Francesa, a Convenção Nacional inaugurara um novo princípio do direito internacional público, o de autodeterminação, que identificava os povos como depositários da soberania. Atendo-se a este princípio, a Convenção declarou extintos os títulos históricos que vinculavam a aristocracia alsaciana ao Sacro Império Romano Germânico, e incorporou este território fronteiriço ao espaço da nação francesa que acabava de se emancipar. Com estes antecedentes a indagação histórica constituía sem dúvida um perigo para a estabilidade nacional, já que inevitavelmente acabaria por rememorar os agravos do passado. Esta é a razão pela qual os construtores de novas ou potenciais naçôes se veem usualmente obrigados a uma tarefa oposta àquela apontada por Renan: escovar a história a contrapelo, como disse Walter Benjamin, com o fim de elaborar um relato próprio politicamente funcional. Neste caso não é o esquecimento, mas a rememoração do agravo real ou fictício o que se torna vital para mobilizar vontades e determinar objetivos. A construção nacional, como todas as empresas políticas que se fixam a uma teleologia histórica, é por definição uma tarefa interminável, uma vez que, se terminada, suporia dar fim ao que se erigiu em um princípio político. Nesta perspectiva, as nações, mais do que um plebiscito cotidiano, como assinalou Renan, ou do que uma realidade intra-histórica, como diria o jovem Unamuno, são um enredo histórico, uma narração socialmente eficaz e sistematicamente posta à prova, cujos consensos, esquecimentos e rememoraçóes correm ao passo da inteligência política do momento. Não se trata nem de provar sua existência nem de promover a sua realização e perdurabilidade. Por isso, o estudo da história tem menos a ver com o interesse pelo pretérito do que com as ambições de futuro.

Toda afirmação sobre o passado é de fato uma reivindicação sobre o presente. Daí também que os planos educacionais e a determinação da grade escolar sejam questóes de primeira ordem política, pois trata-se de inculcar nas novas gerações algum critério coletivo de autorreconhecimento que conceda verossimilhança às decisões tomadas em nome de sociedades que querem se perpetuar. Desde o seu florescimento como disciplina acadêmica, a historiografia subordinou-se com frequência às necessidades ideológicas do Estado nacional, cujo poder é o único capaz de fazer prevalecer uma determinada interpretação do passado. O debate de Andrés Bello com José Victorino Lastarria em meados do século XIX sobre a metodologia mais adequada para escrever a história das novas nações hispano-americanas ilustra bem a natureza dessa empresa. Bello defendia a história com documentos e criticava a história filosófica praticada por Lastarria que, inspirado pela concepção romântica de Jules Michelet, considerava os fatos como meros dados experimentais que deviam servir para descobrir as leis generais da história. $\mathrm{O}$ mesmo debate vingaria décadas depois na Argentina entre Bartolomé Mitre e Vicente Fidel López. Bello não duvidava da função instrutiva da história, porém acreditava que as jovens repúblicas precisavam documentar seu passado e seu nascimento antes de se aventurar em reflexôes de maior alcance sobre a natureza de sua evolução e o sentido de seu destino. Pelo contrário, autores como Lastarria, Sarmiento e López consideravam que a América precisava imperiosamente de uma explicação filosófica das causas e dos efeitos de sua história para atingir a "felicidade e a perfeição do seu povo". A função primordial do estudo da história deveria ser, então, pedagógica e patriótica (Dávila, 2005).

Tudo isso obriga a levar em consideração as condições políticas e culturais na escritura da história e o seu papel na elaboração dos relatos da identidade nacional. A historiografia pré-positivista caracterizava-se por fundir descrição e comentário, desdobrando o significado do relato na própria exposição narrativa. $\mathrm{O}$ método histórico consagrado por Leopold Von Ranke, ao contrário, reivindicou um modo de referência inscrito na facticidade: o historiador tinha que rastrear o passado a partir de seus indícios para apreender os fatos tal como foram, sem se deixar levar pela intuição. Porém, a assimetria entre os modos referenciais do relato histórico e de ficção (extralinguístico em um caso, intralin- 
guístico no outro) não pode velar a existência de elementos reciprocamente emprestados: o passado já não existe e só pode ser reconstruído pela imaginação, a partir de rastros e vestígios, enquanto todo relato, embora seja fictício, é contado como se tivesse sido real. $\mathrm{Na}$ atualidade, refletimos no interior de uma epistemologia pós-positivista, que reconhece a existência de um vínculo entre o saber historiográfico e a inteligência literária. A identificação desse vínculo precisa de uma reflexão de segundo grau sobre as condiçôes últimas de inteligibilidade do relato histórico, um terreno acessível apenas após a virada linguistica sofrida pela epistemologia das ciências sociais. À imitação do conceito kuhniano de paradigma, Hayden White especulou a existência de alguns grandes moldes conceituais na historiografia da Europa do século XIX: dimensão que denominou meta-história. Partindo da consideração da obra histórica como uma estrutura verbal em forma de discurso, que combina dados, conceitos teóricos para explicá-los e uma representação narrada de seu conjunto como algo que aconteceu em tempos passados, White concluiu que os textos historiográficos possuem "um conteúdo estrutural profundo que é de modo geral de natureza poética, e mais especificamente linguística, e que, anterior à crítica, serve como paradigma consensual do que deve ser uma explicação de tipo histórico" (White, 1992, p. 9). Cada um destes paradigmas ou estilos historiográficos seria o resultado de uma combinação específica de estratégias ou modos explicativos articulados em torno do enredo da história, sua argumentação formal e a implicação ideológica do autor. Essa combinação obedeceria a um nivel profundo de consciência do historiador que, mediante um ato poético, escolhe determinadas estratégias conceituais para conseguir um efeito explicativo. Um estilo historiográfico expressaria assim uma pressuposição de caráter metanarrativo sobre a própria natureza do campo estudado e o que cabe esperar da explicação histórica. As conclusōes desta perspectiva estruturalista foram demolidoras para o positivismo, já que basicamente negavam a possibilidade de contar com uma fundamentação absoluta para o método histórico.

Ricoeur também advertiu que um acontecimento não pode ser coberto explicativamente por uma lei geral de inspiração hempeliana se não se encontra inscrito de antemão em uma forma narrativa. ${ }^{1}$ Explicar não só equivale a subsumir fatos a leis; consiste em estabelecer conexões no seio de uma argumentação formal. Idealmente uma história deve poder se explicar por si mesma, de modo que contar $o$ que aconteceu seja igual a contar por que aconteceu. Precisamente por isso a explicação histórica é distinta de uma simples justaposição de acontecimentos: ela se propóe apreendê-los conjuntamente em um ato de razão. Prosseguir uma história não é só incluir nela as surpresas ou os descobrimentos, mas também compreender os episódios já conhecidos como passos conducentes a um fim ulterior. O papel do enredo é fundamental nesta tarefa. Por meio dele os acontecimentos narrados integram-se cronologicamente na configuração de uma história, mas à diferença da crônica, percebida como uma série de incidentes aleatórios e açôes isoladas, um enredo se apresenta como uma totalidade dotada de sentido. Seguindo Northrop Frye e sua teoria sobre as formas arquetípicas do relato, White reconheceu na historiografia europeia do século XIX os traços do drama romântico de redenção, da sátira sobre a impotência humana, da reconciliação irônica entre o mundo do social e o natural e da resignação trágica ante o destino. As concepçôes históricas típicas da época não teriam dependido da natureza dos dados nem das teorias invocadas para sua explicação, mas da construção das respectivas visōes do campo histórico. Daí a impossibilidade de impugnar suas generalizações apelando a novos dados ou interpretaçōes, porque o nível de abstração no qual é realizada essa construção se encontra em um patamar superior: a do ato poético que prefigura o campo histórico e o constitui em explanandum. A construção do enredo histórico mantém-se, então, em um nível distinto ao da própria história narrada, já que não são os acontecimentos inseridos nesta última o que o enredo explica, mas a natureza dessa história como tal, sua tipologia e estrutura argumental. O fio da história narrada permite reconhecer uma configuração única de ações e acontecimentos, enquanto a invenção de um enredo expressa uma determinada forma de apreendê-los no seu conjunto.

O trabalho historiográfico também não está livre de implicaçōes ideológicas. A forma de escre- 
ver a história pressupõe a adoção de uma postura ética por parte do historiador. Neste caso os pressupostos narrativos não se referem tanto ao campo eletivo do potencialmente argumentável, mas à natureza da consciência histórica e, portanto, ao vínculo que pode ser estabelecido entre a explicação dos fatos passados e a prática presente. Embora os acontecimentos pretéritos escapem à nossa percepção, sua organização narrativa condiciona a intencionalidade do relato e revela mais uma vez o parentesco existente entre o relato histórico e o de ficção. Essa intencionalidade pressupõe certo tipo de familiaridade entre o autor e seus destinatários. A capacidade das narraçôes para gerar novos níveis de significação e identidade depende assim mesmo dos tropos discursivos. Na prosa poética, a inovação pelo recurso à metáfora consiste em produzir uma nova pertinência semântica mediante uma atribuição impertinente. Em um relato, a novidade consiste mais propriamente na reinvenção do seu enredo. Em ambos os casos é produzido o que Ricoeur denomina uma sintese do heterogêneo. $\mathrm{Na}$ metáfora o resultado da síntese é uma nova pertinência da predicação; na narração, uma nova congruência na disposição dos acontecimentos contados. $\mathrm{Na}$ metáfora encontramo-nos com uma estratificação tal de significações que uma incongruência de sentido em um nível gera uma afluência de significados em outro nível distinto. Seu potencial simbólico apoia-se precisamente na força de uma interação entre significados discordantes dentro de um marco conceitual unitário. A intensidade dessa interação depende do grau em que a metáfora consegue superar a resistência psíquica provocada pela tensão semântica. Quando essa superação é alcançada, uma metáfora transforma uma falsa identidade em uma analogia pertinente e emotiva: por exemplo, a pátria descrita como Éden ou altar, conforme repetem incansáveis os hinos nacionais latino-americanos (González García, 2005). Quando fracassa, a metáfora é convertida em uma mera extravagância. A pátria espanhola, descrita alegoricamente pelos manuais escolares do franquismo como florido pênsil, dificilmente conseguiu vencer o desconcerto semântico de seus sofridos alunos (Sopeña Monsalve, 2001). De forma análoga ao efeito metafórico, quando a disposição dos acontecimentos no enredo de uma narração é alterada de forma decisiva, a identidade de quem conta e participa da narração sofre uma mutação fundamental. Esses processos de reinterpretação costumam estar ligados à função prática do relato e à implicação ideológica do historiador. Assim, José Antonio Galán, cabeça da insurreição dos comuneros de Socorro, justiçado no Vice-reinado da Nova Granada em 1781, foi convertido em herói romântico e precursor da independência por obra e graça da historiografia patriótica do século XIX. Contudo, ao longo da evolução política da própria sociedade colombiana, o mito patriótico de Galán cedeu um século depois ante o mito revolucionário elaborado pelos historiadores marxistas, que o apresentaram como líder da revolução social e caudilho dos humildes contra um Estado oligárquico (Martínez Garnica, 1997). Por esta razão, uma das primeiras e principais tarefas pedagógicas dos nacionalismos emergentes é elaborar uma narração que ilustre, justifique e culmine a rota histórica da emancipação nacional.

\section{A construção do tempo histórico}

Análises como as de White e Ricoeur nos levam a concluir que toda grande obra histórica constrói uma visão do mundo e seu devir temporal com o concurso dos mesmos meios de articulação narrativa que as filosofias da história. Tal raciocínio abranda a noção convencional sobre a veracidade histórica e reconhecer que o rigor do trabalho historiográfico depende tanto das referências empíricas como da distinção entre os diferentes planos da narração. Se bem que a racionalidade crítica marque um corte epistemológico entre a historiografia como ciência e a narração tradicional ou mítica, estruturalmente advertem-nos que a história é um artifício literário. Do que foi visto se desprende que não é possível alguma imaginação da nacionalidade sem o correspondente relato da identidade coletiva, como também não existe narração sem uma organização simbólica do tempo. $\mathrm{O}$ postulado inverso também é certo, já que o tempo pede emprestado seu significado de determinadas configurações narrativas. Tropos literários como a metáfora, a sinédo- 
que e a metonímia permitem a introdução de novos significados nos relatos históricos, enquanto os arquétipos narrativos facilitam o reconhecimento de determinados esquemas argumentais. Os arquétipos são modelos idealizados de objetos, conceitos ou pessoas, dos quais são derivados como cópia, exemplo ou emulação outras instâncias similares. Sua capacidade simbólica depende da familiaridade cultural de seus destinatários com uma série de uniōes conceptuais. Estes acoplamentos de significado podem estar tão profundamente arraigados que chegam a parecer intrínsecos, como a identificação do símbolo da cruz com a religião cristã, mas nem por isso deixam de ser nexos convencionais. Por isso, o narrador que usar os tropos mais esperados ou familiares no seu contexto cultural conseguirá difundir com maior facilidade e eficácia seus significados. Também o historiador, como escritor, deve se dirigir a um público capaz de reconhecer suas técnicas e formas de narração, pois as estruturas narrativas não são regras inertes, mas formas de uma inércia cultural que as torna inteligíveis.

Um elemento-chave na configuração da imaginação nacional reside precisamente no desenho de uma historicidade ad hoc, o que poderíamos denominar o tempo nacional. Por meio dele conseguimos a inserção do tempo vivido no tempo histórico. Existem, não obstante, conotações importantes nas distintas formas de imaginar a nação, pois nem todos os tempos do desdobramento nacional são iguais. A fórmula republicana, na sua versão jacobina, afirmou o fundamento da vida cívica na abnegação virtuosa do cidadão para com a sua pátria e uma figurada vontade geral. Sua variante norte-americana, filtrada pelo liberalismo, identificou o sentido da comunidade política na busca individual da felicidade. $\mathrm{O}$ republicanismo concedia um modesto papel aos costumes na sua antropologia política. As únicas tradições relevantes para seu repertório normativo diziam respeito ao cultivo das práticas civis. Por essa razão, o culto à história como escola de virtude limitou-se, no republicanismo do século XVIII, a uma interpretação convenientemente estilizada da Antiguidade clássica. $\mathrm{O}$ romantismo abriu-lhe uma nova perspectiva ao representar a história como um voluntarismo em torno do qual são constituídos os caracteres nacionais.
Quando, ao contrário, a identidade coletiva deixa-se arraigar nas concreçōes intransferíveis da etnia, da cultura ou da religião, o tempo imaginário da história nacional pode ser encenado de muitas outras maneiras: como emancipação, ressurgimento, redenção, catarse ou regressão constante às origens. Mitos fundacionais, epopeias e sacrifícios heroicos encontram-se narrativamente a serviço de uma profundidade histórica perseguida como aval de autenticidade. Esta organização salvífica da historicidade é um arquétipo de indubitável raiz judaico-cristã de que o progresso positivista e as concepções Whig e romântica da história como avanço inexorável para maiores patamares de liberdade representam os capítulos mais derradeiros.

A imaginação da nação como uma simultaneidade de existências individuais, organicamente subsumidas e deslocadas de forma unitária e compacta através de um tempo homogêneo, vazio e mensurável implicava, segundo Anderson, uma ruptura com o tempo messiânico do cristianismo medieval, que fundia passado e futuro no eterno presente da salvação providencial (Anderson, 1992, p. 22). A feitura poética dos relatos nacionais obriga, contudo, a qualificar esta asseveração. Retomando a taxonomia histórico-literária de White, podemos constatar que este tipo de narração costuma reproduzir os padrões do drama romântico de redenção, que por sua vez e ao seu modo reflete a percepção salvífica do tempo cristão. Neste esquema, o sujeito vence e se libera das dificuldades que lhe são impostas pelo mundo e pela história. "É o tipo de drama" - afirma White - "associado com a lenda do Santo Graal ou com o relato da ressurreição de Cristo na mitologia cristã. É um drama do triunfo do bem sobre o mal, da virtude sobre o vício, da luz sobre as trevas e da transcendência última do homem sobre o mundo no qual foi aprisionado pela Queda" (White, 1992, p. 19). Consequentemente, os relatos nacionais costumam descrever uma trajetória escatológica ao longo da qual as nações nascem, despertam, caem, são redimidas ou assumem seu destino. O drama nacional pode também ser de índole trágica. Neste caso a queda do sujeito e a comoção de seu mundo reverberam sobre quem the sobrevive, que toma consciência das leis que dominam a existência histórica. 
Em seu estudo do messianismo político ocidental, Michael Walzer identificou a imaginação típica da mudança revolucionária na nossa cultura como uma epopeia na qual o grupo escolhido reproduz o ciclo do povo hebreu na sua busca pela terra prometida, tal e como é descrito nos textos bíblicos do Exodo e os Números. Este ciclo recolhe os momentos de opressão, liberação, estabelecimento de um novo pacto político, explosão do conflito interno e, por fim, refundação social. Encontrar-nos-íamos ante um arquétipo narrativo que ao longo da história ocidental se superpôs como projeção utópica ao relato dos acontecimentos em situações de crise social e regeneração política. Este esquema seria reconhecível em contextos tão diversos quanto as peregrinaçōes puritanas para o além-mar após a Reforma protestante, o anelado retorno para a África do rastafarianismo ou a luta dos negros estadunidenses pelos direitos civis. A ênfase nos distintos momentos da sequência escatológica pode variar em cada relato, porém Walzer adverte que não se trata de uma história ubíqua. A escatologia bíblica não é um padrão universal: "Pertence ao Ocidente, mais concretamente aos judeus e aos cristãos ocidentais, e sua fonte, sua versão original, é o êxodo de Egito do povo de Israel [...]. Em outras culturas os homens e as mulheres leem outros livros, contam diferentes histórias, enfrentam distintas escolhas" (Walzer, 1985, p. 133). Na nossa tradição, a terra prometida só pode ser atingida mediante a travessia do deserto. Porém existe uma possibilidade distinta e igualmente familiar: o êxodo interminável, pois a terra de promissão ainda nos aguarda ao final do percurso. Essa foi sempre, conforme Walzer, a grande tentação política ocidental: o messianismo que impulsiona uma busca infinita da salvação.

Não é difícil reconhecer este mesmo arquétipo na imaginação nacional. A parábola bíblica do êxodo pode se reformular como peregrinação histórica ou geográfica de um povo revoltado contra a opressão forânea sob a guia de um líder carismático. Para o sionismo, classificado por Gellner (1983) como um subtipo do nacionalismo de diáspora, o povo judeu era uma nação errante que devia retornar à terra de Israel, sua razão de ser. A noção do lar nacional, ora como Urheimat - berço e origem - ora como terra de promissão, é um elemento central na representação do acoplamento histórico entre povo e terra. Essa associação não tem por que obedecer necessariamente a um roteiro providencial, porém a fusão ontológica de ambos é o que caracteriza a uma etno-paisagem como tal.

Assim, a chegada de Árpád à planície panôni$\mathrm{ca}$, à frente das tribos magiares, majestosamente representada no ciclorama construído por Feszty em 1896 para comemorar seu primeiro milênio, é descrita no relato nacional húngaro como "a ocupação do nosso território" (Honfoglalás) e constitui o momento fundacional da nação. A ideia de língua própria em um nacionalismo muito longe deste, como o catalão, reproduz em um nível distinto a noção do lugar primordial, só que neste caso o espaço nacional é um espaço linguístico. Mesmo conservando suas instituições políticas de autogoverno, a hipotética desaparição da língua catalã equivaleria na imaginação dos nacionalistas à desaparição da nação. Por isso os Països catalans formam um espaço político imaginário construído com base em uma concepção linguística do território. Não muito distinto é o conceito de Euskal Herria como referência ao espaço da cultura vasca, segundo o define a Sociedade de Estudos Vascos, embora o papel do euskera nessa definição resulte mais ambíguo do que no caso catalão. Em ambos os exemplos o território imaginado não corresponde às demarcações administrativas e políticas realmente existentes, mas com a imaginação geográfica de uma representação cultural. Seria interessante contrastar estes dois exemplos com um nacionalismo mais exitoso em termos de autodeterminação política, como o irlandês, no qual o papel simbólico do gaélico foi tradicionalmente submetido a outras variáveis culturais e políticas. Nos nacionalismos cívicos, a representação do tempo histórico não é menos importante do que nos nacionalismos culturais, porém neste caso a imaginação costuma se projetar predominantemente para o futuro, como vontade, eleição ou destino providencial. Esta última acepção foi recorrente na legitimação do colonialismo, como se pode facilmente reconhecer no destino manifesto dos Estados Unidos ou na mission civilisatrice da França republicana.

Ao tentar transladar para fora do contexto europeu os debates metodológicos da historiografia contemporânea, o historiador colombiano Germán 
Colmenares chamou a atenção sobre a peculiar natureza das convençōes narrativas adotadas pelos historiadores hispano-americanos do século XIX (Colmenares, 1989). Seguindo o trabalho de Hyden White, Colmenares tentou mostrar as tensões cognitivas geradas na América hispânica pela aplicação exótica dos cânones interpretativos europeus, o que definiu como uma colisão entre as convenções teóricas e a cultura local. As histórias pátrias escritas durante o século XIX encobririam a solução ideológica a um profundo conflito cultural, a saber, a tentativa de romper radicalmente com um passado colonial que reaparecia íntegro nas formas de vida das massas latino-americanas. Textos como os de Bartolomé Mitre sobre a Argentina, Diego Barros Arana sobre o Chile, Rafael María Baralt sobre a Venezuela ou José Manuel Restrepo sobre a Colômbia responderiam à inquietude e frustração de intelectuais que, por um lado, desdenhavam os valores coloniais que haviam perdido todo o seu prestigio; por outro, a própria inserção pessoal em uma estrutura social ainda colonial levava-os a restringir a uma pequena minoria o acesso ao progresso associado com as novas ideias. A institucionalização do enredo histórico recolhido nesses textos levou a convertê-los, finalmente, na crônica de uma epifania nacional que devia certificar o cumprimento íntegro das promessas da independência. A ruptura mental com o passado alimentou assim a ilusão de que as sociedades americanas podiam se moldar plasticamente às instituições políticas e legais desligadas da experiência local. O efeito foi a condenação sumária das formas de vida vernáculas e a alienação cultural das elites em relação a suas próprias sociedades. A cultura barroca ibero-católica conseguira incorporar assimetricamente distintos grupos no tronco de uma sociedade colonial estamental, corporativa e etnicamente estratificada. Depois da independência, contudo, as elites republicanas foram incapazes de substituir essa velha estrutura por uma sociedade liberal de indivíduos e gerar uma ideologia hegemônica susceptível de integrar funcionalmente as novas tensões e conflitos de interesses. $\mathrm{O}$ resultado foi um enfoque excludente, uma dicotomia entre civilização e barbárie que dividia a população das novas sociedades nacionais entre gente de razão e uma multidão turbulenta e inassimilável.
A função da historiografia nesse processo cobra toda sua evidência ao ser inserida na construção das repúblicas. A nova intelligentsia crioula, que nelas substituiu a Igreja como intelectual orgânico, pertencia a uma elite relativamente homogênea na sua extração social e formação cultural. Entre as primeiras geraçôes de historiadores latino-americanos abundam os presidentes, os diplomatas e os parlamentares, com frequência os únicos com acesso a documentos e arquivos necessários para o trabalho de pesquisa. Além do seu estrato social, a historiografia patriótica desenvolvida por estes intelectuais reflete uma profunda mudança no próprio significado da escritura da história. As primeiras geraçôes das classes letradas republicanas encontravam-se constitutivamente incapacitadas para a melancolia colonial. O corte traumático das relações políticas com a metrópole condicionara de forma radical seu olhar histórico. Em face da função tradicional da história sacra, dirigida à salvação das almas, ou das velhas crônicas e relações da conquista, interessadas em reivindicar privilégios e demonstrar linhagens, as novas historiografias nacionais estavam impulsionadas por uma intenção instrutora: a concepção da história como escola de virtude cívica e guia política para o futuro. Daí a típica feitura épica dos seus relatos e sua visão heroica da história. Em termos narrativos, o ponto de partida desses relatos pode ser encontrado nas revoluçōes de independência. Essa é a ação maiêutica que divide o tempo em antes e depois, entre a história nacional e a sua pré-história. O problema nascia do fato de que os esquemas narrativos prefixados pela maneira europeia de escrever a história impediam a compreensão das sociedades americanas neles descritas. $\mathrm{O}$ resultado de tudo isso foi una distorção generalizada na interpretação da realidade local. Os temas aprovados pelos cânones europeus do momento, como a busca romântica do índio nobre, a evolução social ou a preocupação positivista pelo progresso, gozavam de um interesse prioritário entre os historiadores latino-americanos. Historiadores, políticos e reformadores sociais tendiam sistematicamente a comparar seus países com os do norte da Europa e os Estados Unidos. Contudo, a insistência em julgar as suas próprias sociedades com base em experiências e condiçōes que lhes eram alheias, separava-as 
do seu contexto original e, inevitavelmente, levava-os a concluir pelo seu caráter deficitário (Burns, 1998). A frustração de Bolívar com a implantação da virtude cívica na América que acabava de ser emancipada, dos positivistas do século XIX com o atraso econômico do continente, ou dos marxistas latino-americanos do século XX com a reticente consciência proletária das massas rurais e indígenas, reflete uma reiterada síndrome de alienação na forma de representação da própria sociedade, fortalecendo a ideia de que sua evolução obedece a desígnios que apenas uma minoria seleta pode decifrar.

\section{Notas}

1 De acordo com o modelo que Carl Gustav Hempel batizou como nomológico-dedutivo, explicar um fato consiste em deduzir o enunciado que o descreve (explanandum) a partir de leis científicas gerais e condições iniciais particulares (explanans). Explicar consistiria, então, em subsumir regularidades em um conjunto mais inclusivo de leis abarcadoras (covering laws).

\section{BIBLIOGRAFIA}

ANDERSON, Benedict. (1992), Imagined communities: reflections on the origin and spread of nationalism. Londres, Verso.

BURNS, Bradford. (1998), "Ideology in nineteenth century Latin American historiography". The Hispanic American Historical Review, 58 (5): 409-431.

COLMENARES, Germán. (1989), Las convenciones contra la cultura. 3 ed. Santa Fe de Bogotá, Tercer Mundo.

DÁVILA, Luis Ricardo. (2005), La América noble y republicana. Medellín, Universidad Pontificia Bolivariana.

FRYE, Northrop. (1957), The anatomy of criticism: four Essays. Princeton, Princeton University Press.

GEERTZ, Clifford. (1987), La interpretación de las culturas. Barcelona, Gedisa.

GELLNER, Ernest. (1983), Nations and nationalism. Ithaca, Cornell University Press.
GONZÁLEZ GARCÍA, José María. (2005), “¡Libertad o con gloria morir! Himnos nacionales en Latinoamérica”, in F. Colom González (ed.), Relatos de nación: la construcción de las identidades nacionales en el mundo hispánico, Madri/Frankfurt, Iberoamericana/Vervuert, pp. 729-748.

HASTINGS, Adrian. (1997), The construction of nationhood: ethnicity, religion, and nationalism. Cambridge, Cambridge University Press.

LENK, Kurt. (1982), El concepto de ideología. Buenos Aires, Amorrortu.

MARTÍNEZ GARNICA, Armando. (1997), "El movimiento histórico del mito: José Antonio Galán en la conciencia nacional”. Memoria, 28: $12-55$.

PÉREZ VEJO, Tomás. (2004), España en el debate público mexicano (1836-1867). México, El Colegio de México, Instituto Nacional de Antropología e Historia.

RENAN, Ernest. (1992), Qu est-ce qu'une nation? Bizou, Presses Pocket.

RICOEUR, Paul. (1983), Temps et récit. Paris, Éditions du Seuil.

SOMERS, Margaret R. (1994), "The narrative constitution of identity: a relationship and network approach". Theory and Society, 23 (5): 605-649.

SOPEÑA MONSALVE, Andrés. (2001), El florido pensil: memoria de la escuela nacional católica. Barcelona, De Bolsillo.

WALZER, Michael. (1985), Exodus and revolution. Nova York, Basic Books.

WHITE, Hyden. (1992), Metahistoria: la imaginación histórica en la Europa del siglo XIX. México, Fondo de Cultura Económica. 


\section{A NAÇÃO COMO RELATO: A ESTRUTURA NARRATIVA DA IMAGINAÇÃO NACIONAL}

\section{Francisco Colom González}

Palavras-chave: Nacionalismo; Identidade; Narratividade; Imaginários nacionais; Historiografia.

Neste artigo explora-se a dimensão narrativa na construção dos imaginários nacionais. Os alicerces dele são o vínculo sublinhado por Paul Ricoeur entre o tempo e a narração, e a noção de "metahistoria" elaborada pelo Hyden White. Analisa-se as condições de inteligibilidade dos relatos historiográficos em geral, da sua afinidade estrutural com os relatos de ficção e do rol dos dispositivos narrativos na formação dos ideologemas nacionalistas. Como ilustração desta visão, o texto discute diversos exemplos da tradição historiográfica hispano-americana.

\section{THE NATION AS NARRATION: THE NARRATIVE STRUCTURE OF NATIONAL IMAGINATION}

\section{Francisco Colom Gonzáles}

Keywords: Nationalism; Identity; Narrativity; National imaginaries; Historiography.

This paper explores the narrative dimension of national imaginaries. Drawing on the link established by Paul Ricoeur between time and narrative, and on Hyden White's notion of 'metahistory' as the level from which intelligibility is conveyed to historical narration, the paper discloses the performative role of literary tropes in nationalist discourse and resorts to several examples from the Spanish American historiographical tradition in order to exemplify its case.

\section{LA NATION COMME RÉCIT: LA STRUCTURE NARRATIVE DE L'IMAGINATION NATIONALE}

\section{Francisco Colom González}

Mots-clés: Nationalisme; Identité; Narrativité; Imaginaire national; Historiographie.

Cet article explore la dimension narrative dans la construction de l'imaginaire national. Il se fonde sur le lien établi par Paul Ricoeur entre le temps et le récit, et sur la notion de "métahistoire " développée par Hyden White. L'article analyse les conditions d'intelligibilité des récits historiographiques en général, leur affinité structurelle avec les récits de fiction et la liste des dispositifs de narration dans la formation des idéologèmes nationalistes. Pour illustrer ce point de vue, le texte discute divers exemples de la tradition historiographique hispano- américaine. 